\title{
Hubungan Kebijakan Pandemi COVID-19 Terhadap Faktor Pernikahan Usia Remaja Kecamatan Pringgabaya, Lombok Timur, NTB
}

\author{
Nurwaningsih ${ }^{1}$, Ika Wijayanti, Ratih Rahmawati \\ Universitas Mataram
}

\begin{abstract}
The study aims to know the relationship of pandemic COVID-19 policy toward teenager marriage factor. The method used in this study is quantitative method with associative approch. Data collection techniques using questionnaires, while data analysis techniques use spearman correlation analysis the results showed that there was a significant relationship between COVID-19 Pandemic policy toward teenage marriage factor with relationship rate off $8,11 \%$. Also Policy in pandemic covid-19 raises the awareners of healthy and clean life exercise a healthy lifestyle by following the healthy protocols applied by the goverment. But on the others hand, there is an event of latent or an uncological function of the policy of COVID-19 pandemic is one of the factor behind teenage marriage, where the policies are related to social restrinctions and network learning (online), socioeconomic, cultural and environment become the factor that cause teenagers in marriage.
\end{abstract}

Keywords : Government Policy, COVID-19 Pandemic, Teenage Marriage

\begin{abstract}
Abstrak
Penelitian ini bertujuan untuk mengetahui hubungan kebijakan pandemi COVID-19 terhadap faktor pernikahan usia remaja. Metode yang digunakan dalam penelitian ini adalah metode kuantitatif dengan pendekatan asosiatif. Teknik Pengumpulan data menggunakan kuesioner, sedangkan teknik analisis data menggunakan analisis Korelasi Spearman. Hasil penelitian menunjukkan bahwa terdapat hubungan yang signifikan antara kebijakan pandemi COVID-19 terhadap faktor pernikahan usia remaja dengan tingkat realibilitas sebesar 8,11\%. Kebijakan di masa pandemi COVID-19 memunculkan adanya fungsi manifes atau fungsi yang diharapkan yakni memunculkan adanya kesadaran akan hidup sehat dan bersih serta menjalankan pola hidup sehat dengan cara mengikuti protokol kesehatan yang diterapkan oleh pemerintah. Namun di sisi lain, terdapat fungsi laten atau fungsi yang tidak diharapkan dari adanya kebijakan di masa pandemi COVID-19 yakni menjadi salah satu faktor pernikahan usia remaja di mana kebijakan terkait pembatasan sosial dan pembelajaran jaringan (online), sosial ekonomi, budaya dan lingkungan menjadi faktor yang mempengaruhi remaja dalam melakukan pernikahan.
\end{abstract}

Kata Kunci : Kebijakan Pemerintah, Pandemi COVID-19, Pernikahan Usia Remaja

\footnotetext{
${ }^{1}$ nurwa.ningsih20@gmail.com
} 


\section{Pendahuluan}

Tahun 2020 virus corona atau lebih dikenal dengan COVID-19 mulai menyebar di seluruh dunia. Pada awalnya virus ini diduga berasal dari hewan yaitu kelelawar, hingga pada akhir bulan Desember tahun 2019 diketahui bahwa virus corona menginfeksi manusia. Januari 2020, Komisi Nasional Kesehatan China mengkonfirmasi bahwa virus tersebut dapat menular antar manusia. Virus corona dapat tertular melalui interaksi antar manusia dan penyebarannya sangat cepat, membuat World Health Organization (WHO) atau badan kesehatan dunia menetapkan COVID-19 sebagai pandemi global (Ardian, 2020).

Pandemi COVID-19 telah berdampak pada berbagai sisi kehidupan masyarakat, mulai dari kesehatan, ekonomi, pendidikan, pemerintahan, hingga kebiasaan-kebiasaan manusia dalam kehidupan sehari-hari. Dalam bidang kesehatan puluhan ribu jiwa telah menjadi korban dari COVID-19. Tercatat untuk di Negara Indonesia per tanggal 31 Oktober 2020 kasus pasien terjangkit COVID-19 mencapai 407.000 jiwa, dengan tambahan kasus sekitar 1.000 kasus perhari. Angka tersebut termasuk cukup tinggi bahkan melebihi negara asalnya yaitu Wuhan, China (Ardian, 2020).

Secara sosiologis, pandemi COVID-19 telah menyebabkan perubahan sosial yang tidak direncanakan. Artinya, perubahan sosial terjadi secara cepat dan kehadirannya tidak dikehendaki oleh masyarakat. Dunia pendidikan juga turut terkena dampak dari adanya pandemi global COVID-19, di mana seluruh kegiatan belajar mengajar mulai dari tingkat PAUD (Pendidikan Anak Usia Dini) hingga Perguruan Tinggi dihentikan dan dilakukan melalui sistem jaringan (https://kompas.com/virus-corona/2020).

COVID-19 berpengaruh terhadap sistem pemerintahan negara, di mana setiap pemimpin negara dituntut sigap dalam membuat dan menerapkan berbagai kebijakan guna memulihkan kondisi negara akibat pandemi. Kebijakan yang diterapkan pemerintah di masa pandemi COVID-19. Pembatasan Sosial (Social Distancing) adalah serangkaian tindakan pengendalian infeksi nonfarmasi yang dimaksudkan untuk menghentikan atau memperlambat penyebaran penyakit menular. Tujuan dari pembatasan sosial adalah untuk mengurangi kemungkinan 
kontak antara orang terinfeksi dan orang lain yang tidak terinfeksi. Sehingga dapat meminimalkan penularan penyakit. Pembatasan sosial diberlakukan guna mencegah timbulnya penyebaran COVID-19 dalam skala yang lebih luas. Tidak semua Provinsi di Indonesia memberlakukan adanya pembatasan baik dalam skala besar maupun kecil, namun seluruh Provinsi di Indonesia diwajibkan untuk menerapkan protokol kesehatan dengan ketat, salah satunya yaitu pembatasan sosial atau pembatasan secara fisik (Anung, 2020).

Sistem Pembelajaran Jaringan (Online) merujuk pada Keputusan Bersama Empat Menteri Nomor 01/KB/2020 tentang Panduan Penyelenggaraan Pembelajaran pada Tahun Ajaran 2020/2021 di Masa Pandemi COVID-19 bahwa metode pembelajaran di Lakukan Secara Daring. Pandemi COVID-19 menjadikan institusi pendidikan mendadak menyelenggarakan pembelajaran jarak jauh, terutama secara daring. Pembelajaran jarak jauh adalah pembelajaran yang cara penyampaian materi atau bahan ajar dan interaksinya dilakukan melalui perantara teknologi internet.

Data kasus pernikahan usia remaja di Kabupaten Lombok Timur pada tahun 2020 mencapai 42 kasus. Angka tersebut jauh lebih tinggi dari jumlah kasus pernikahan usia remaja pada tahun 2019. Kasus paling banyak terjadi di Kecamatan Jerowaru dan Pringgabaya (https://Insidelombok.id, 2021)

Berdasarkan observasi awal yang dilakukan peneliti terhadap beberapa responden terkait masalah yang mulai timbul dari para pelajar setelah adanya kebijakan pembelajaran daring. Mulai dari masalah kehadiran hingga tidak mengerjakan tugas dengan berbagai alasan serta menghilang tanpa kabar karena telah melakukan pernikahan secara tertutup dan tidak diketahui oleh pihak sekolah. Selain itu, berdasarkan pernyataan beberapa tokoh agama dan kepala dusun setempat bahwa terdapat peningkatan yang cukup signifikan terkait pernikahan usia remaja di setiap Desa dari tahun-tahun sebelumnya dengan berbagai sebab dan alasan. 
Data terkait jumlah kasus pernikahan usia remaja di Desa Bagek Papan dan Desa Apitaik Kecamatan Pringgabaya Kabupaten Lombok Timur. Total kasus pernikahan di Desa Bagek Papan dari tahun 2020 hingga bulan Maret tahun 2021 sebanyak 143 kasus, sedangkan untuk Desa Apitaik terdapat 157 kasus pernikahan. Berangkat dari pemaparan permasalahan tersebut, peneliti tertarik untuk melakukan penelitian dan menganalisis hubungan kebijakan pemerintah di masa pandemi COVID-19 terhadap faktor pernikahan usia remaja di Kecamatan Pringgabaya Kabupaten Lombok Timur. Oleh karena itu, berdasarkan pemaparan di atas peneliti tertarik untuk mengkaji bagaimana hubungan kebijakan pandemi COVID-19 terhadap faktor pernikahan usia remaja di Kecamatan Pringgabaya Kabupaten Lombok Timur?

Adapun penelitian terdahulu yang mengkaji permasalahan yang serupa yaitu penelitian yang dilakukan oleh Sri Hariyati (2020) tentang Pengaruh COVID19 Terhadap Kondisi Sosial Budaya di Kota Malang dan Konsep Strategis dalam Penanganannya. Berdasarkan hasil penelitian, ditemukan bahwa penyebaran COVID-19 di Kota Malang terus mengalami kenaikan dan memberikan dampak sosial budaya ke arah negatif, khususnya setelah diberlakukannya Pembatasan Sosial Berskala Besar (PSBB). Dari mulai tingkat perceraian semakin tinggi, interaksi sosial terbatas, hingga pengaruh sosial pada perempuan dan anak-anak. Maka dari itu, perlu diberlakukan langkah strategis dengan penggunaan demografi sosial berdasarkan penurunan mobilitas sosial masyarakat di Kota Malang.

Berdasarkan hasil penelitian, ditemukan bahwa penyebaran COVID-19 di Kota Malang terus mengalami kenaikan dan memberikan dampak sosial budaya ke arah negatif, khususnya setelah diberlakukannya Pembatasan Sosial Berskala Besar (PSBB). Dari mulai tingkat perceraian semakin tinggi, interaksi sosial terbatas, hingga pengaruh sosial pada perempuan dan anak-anak. Maka dari itu, perlu diberlakukan langkah strategis dengan penggunaan demografi sosial berdasarkan penurunan mobilitas sosial masyarakat di Kota Malang.

Ningsih dan Rahmadi (2020) tentang Dampak Pernikahan Dini di Desa Keruak Kecamatan Keruak Kabupaten Lombok Timur. Adapun hasil penelitian menunjukkan, dampak yang ditimbulkan dari tingginya angka pernikahan dini 
yaitu, putus sekolah, rentan mengalami depresi, dan terjadinya Kekerasan Dalam Rumah Tangga (KDRT). Aisyah (2018) tentang Hubungan Tingkat Pengetahuan Remaja Tentang Pernikahan Dini Dengan Kejadian Pernikahan Dini di Kecamatan Saptosari Kabupaten Gunungkidul. Hasil penelitian adalah responden yang banyak melakukan pernikahan dini adalah responden yang memiliki pengetahuan kurang tentang pernikahan dini. Terdapat hubungan yang signifikan antara tingkat pengetahuan remaja tentang pernikahan dini dengan kejadian pernikahan dini di Kecamatan Saptosari Kabupaten Gunungkidul Yogyakarta.

\section{Metode Penelitian}

Metode penelitian yang digunakan dalam penelitian ini adalah metode penelitian Kuantitatif dengan pendekatan asosiatif. Lokasi penelitian dilakukan di Kecamatan Pringgabaya Kabupaten Lombok Timur. Penelitian ini berfokus di Desa Bagek Papan dan Desa Apitaik karena data terkait jumlah kasus pernikahan usia remaja yang tinggi serta pertimbangan waktu, lokasi dan biaya penelitian. Unit analisis dalam penelitian ini individu yaitu remaja rentang usia 13 - 18 Tahun yang sudah melakukan pernikahan dan tinggal di Desa Apitaik dan Desa Bagek Papan. Populasi dalam penelitian ini yaitu seluruh remaja rentang usia 13 - 18 Tahun yang berjumlah 300 orang dan jumlah sample dalam penelitian ini yaitu 75 responden. Teknik pengambilan sample yang digunakan yaitu Probability Sampling dengan teknik Simple Random Sampling yaitu teknik pengambilan sample secara acak tanpa memperhatikan stara atau tingkatan. Variabel dalam penelitian ini yaitu variabel bebas atau Independent Variable yaitu kebijakan pandemi COVID-19, dan variabel terikat atau Dependent Variable yaitu faktor pernikahan usia remaja. Skala pengukuran yang digunakan yaitu skala ordinal. Prosedur pengumpulan data dalam penelitina ini menggunakan observasi lapangan yaitu menggali informasi serta datadata terkait kasus pernikahan usia remaja kepada pihak-pihak atau tokoh yang bersangkutan. Wawancara terstruktur menggunakan kuesioner yang diberrikan kepada responden serta dokumentasi. Pengujian intrumen menggunakan uji validitas dan menghasilkan 43 pertanyaan dengan nilai r.Hitung lebih besar dari 
r.Tabel (0,334). Uji reliabilitas menghasilkan nilai untuk variabel bebas sebesar 0,815 dan untuk variabel terikat sebesar 0,835 dengan tingkat reliabilitas sangat tinggi. Analisis data yang digunakan yaitu Uji Korelasi Spearman.

\section{Hasil dan Pembahasan}

\section{Hubungan Kebijakan Pandemi COVID-19 Terhadap Faktor Pernikahan Usia Remaja}

\section{Pandemi COVID-19}

Variabel pandemi COVID-19 berkaitan dengan kebijakan-kebijakan yang diterapkan di masa pandemi COVID-19. Kebijakan tersebut diantaranya seperti penerapan protokol kesehatan yang berlaku di masa pandemi. Selain itu, pembelajaran daring (jaringan) yang di terapkan bagi sekolah-sekolah, serta aturan pembatasan sosial dan larangan melakukan mobilitas guna memutus rantai penyebaran COVID-19. Variabel pandemi COVID-19 memiliki indikator yakni

pengetahuan yang berkaitan dengan pengetahuan dan respon masyarakat terhadap berbagai kebijakan yang anjurkan pemerintah di masa pandemi.

Terkait kebijakan di masa pandemi COVID-19 masyarakat menjalankan dan menaati peraturan dengan baik di masa pandemi COVID-19 sebanyak 61,3\% atau 64 responden menjawab menaati protokol dan peraturan dengan baik. Peraturan terkait pembelajaran daring mendapat banyak penolakan dari responden terlihat dari $72 \%$ atau 54 responden menjawab tidak setuju terkait pembelajaran daring di masa pandemi COVID-19.

Hal ini dikarenakan sistem pembelajaran daring tidak efektif bagi siswa terlihat dari $80 \%$ atau 60 responden menjawab Ya terkait pembelajaran daring yang tidak efektif di masa pandemi COVID-19. Ketidakefektifan pembelajaran daring berakibat pada siswa yang tidak dapat memahami materi pembelajaran, terdapat 89,3\% atau 67 responden menjawab Ya.

Pengetahuan responden terkait pernikahan usia remaja terindikasi rendah hal ini terlihat dari $54,7 \%$ atau 41 responden menjawab tidak mengetahui terkait larangan menikah di usia remaja oleh pemerintah. Selain itu, pengetahuan remaja tentang dampak pernikahan usia remaja juga cukup rendah di mana terdapat $60 \%$ 
atau 45 responden menjawab tidak mengetahui dampak-dampak yang terjadi akibat pernikahan usia remaja. Pengetahuan terkait pendidikan seks (seks education) juga sangat rendah hal ini dikarenakan pendidikan seks tidak pernah di bahas pada lembaga formal seperti sekolah, terdapat $82,7 \%$ atau 62 responden menjawab tidak pernah mempelajari tentang pendidikan seks atau pernikahan usia remaja di sekolah. Selain itu para remaja juga tidak pernah mengikuti seminar ataupun sosialisasi terkait bahaya pernikahan usia remaja ataupun pendidikan tentang seks, terdapat $76 \%$ atau 57 responden menjawab tidak.

\section{Faktor Pernikahan Usia Remaja}

Faktor pernikahan usia remaja berkaitan dengan hal-hal yang melatarbelakangi remaja untuk melakukan pernikahan di bawah usia 19 tahun diantarannya sebagai berikut :

a. Kondisi Sosial Ekonomi

Kondisi sosial ekonomi berkaitan dengan kondisi sosial dan ekonomi responden sehingga menjadi faktor terjadinya pernikahan di usia remaja pada masa pandemi COVID-19. Kesadaran masyarakat akan bahaya pernikahan usia remaja masih rendah terlihat dari peran dan fungsi masyarakat sebagai agen kontrol sosial atau pengawas dalam mencegah terjadinya pernikahan usia remaja, terlihat dari $90,7 \%$ atau 68 responden menjawab Ya terkait masyarakat masih tidak mempermasalahkan serta membiarkan adanya pernikahan usia remaja. Selain itu faktor ekonomi menjadi salah satu faktor terjadinya pernikahan usia remaja, terdapat $94,7 \%$ atau 71 responden menjawab Ya terkait alasan melakukan pernikahan usia remaja.

b. Budaya

Budaya berkaitan dengan tradisi atau kepercayaan terkait menikah di usia remaja untuk menghindari dari perbuatan dan pergaulan buruk dan kaitannya dengan alasan responden melakukan pernikahan di usia remaja. Faktor budaya menjadi salah satu faktor dalam mempengaruhi pernikahan usia remaja, terbukti dari $77,3 \%$ atau 58 responden menjawab menikah di usia remaja karena pengaruh 
budaya atau budaya menikah di usia remaja yang sudah lumrah dilakukan di lingkungan sekitar sehingga bukan hal yang tabu (asing). Selain itu 60\% atau 45 responden mengaku tidak mendapat teguran dari berbagai pihak terkait pernikahan usia remaja yang dilakukan. Terdapat $74 \%$ atau 56 responden menjawab bahwa budaya merarik kode' masih tetap berkembang dan dijalankan oleh masyarakat.

c. Lingkungan

Lingkungan berkaitan dengan lingkungan tempat tinggal atau lingkungan masyarakat, lingkungan sekolah, serta lingkungan keluarga tempat responden melakukan interaksi sosial serta pengaruhnya terhadap keputusan responden melakukan pernikahan di usia remaja pada masa pandemi COVID-19. Faktor lingkungan menjadi salah satu faktor yang mempengaruhi remaja untuk melakukan pernikahan di usia remaja, terdapat $90,7 \%$ atau 68 responden mengaku bergaul dengan teman-teman yang juga merupakan remaja yang telah melakukan pernikahan di usia remaja, sehingga alasan menikah di usia remaja dipengaruhi oleh lingkungan bermain atau lingkungan pertemanan. Hal ini dibuktikan dengan 70,7\% atau 53 remaja menjawab Ya terkait alasan menikah di usia remaja. Selain itu, 'nikah muda' sedang menjadi tren baru di tengah-tengah masyarakat sehingga banyak remaja yang menikah karena pengaruh tren atau gaya hidup baru, terbukti dari $88 \%$ atau 66 responden menjawab Ya terkait alasan menikah di usia remaja.

Lingkungan keluarga juga cukup besar pengaruhnya dalam pernikahan usia remaja, terdapat $76 \%$ atau 57 responden menjawab Ya terkait faktor utama menikah dikarenakan keinginan untuk lepas dari tekanan orang tua atau memiliki hubungan yang kurang baik dengan orang tua. Selain itu, terdapat $60 \%$ atau 45 responden menjawab Ya terkait adanya paksaan dari kedua orang tua untuk melakukan pernikahan di usia remaja. Hal ini memperlihatkan bahwa adanya fungsi keluarga yang tidak berjalan dengan baik sehingga menyebabkan seorang anak melakukan pernikahan di usia yang belum diperbolehkan untuk menikah.

Hasil analisis ini mendeskripsikan hasil temuan data dan hubungan kebijakan pandemi COVID-19 terhadap faktor pernikahan usia remaja. Keterkaitan antara variabel tersebut kemudian kembali diperkuat dengan hasil pengujian 
hipotesis menggunakan teknik Uji Korelasi Spearman. Adapun hasil analisis data variabel kebijakan pandemi COVID-19 terhadap faktor pernikahan usia remaja.

Tabel 3.1

Analisis Uji Korelasi Spearman

\begin{tabular}{|c|c|c|c|}
\hline & & Kebijakan & Faktor \\
\hline \multirow{3}{*}{ kebijakan } & Pearson Correlation & 1.000 & ,811" \\
\hline & Sig. (2-tailed) & &, 000 \\
\hline & $\mathrm{N}$ & 75 & 75 \\
\hline \multirow{3}{*}{ faktor } & Pearson Correlation & ,811** & 1.000 \\
\hline & Sig. (2-tailed) & ,000 & \\
\hline & $\mathrm{N}$ & 75 & 75 \\
\hline
\end{tabular}

Berdasarkan output di atas diketahui bahwa $\mathrm{N}$ atau jumlah data adalah 75 responden. Nilai sig (2-tauled) variabel X sebesar 0,000 lebih kecil dari alpha 0,05 maka Ho ditolak artinya terdapat hubungan yang signifikan antara kebijakan pandemi COVID-19 (X) terhadap faktor pernikahan usia remaja (Y). Nilai Coreelation Coefficient (koefisien korelasi) sebesar 0,811 maka dapat disimpulkan bahwa tingkat hubungan kebijakan pandemi COVID-19 terhadap faktor pernikahan usia remaja sangat tinggi.

Robert K. Merton membedakan teori struktural fungsional dalam dua fungsi yakni fungsi manifes dan fungsi laten. Fungsi Manifest adalah fungsi yang diharapkan atau fungsi yang disadari dari sebuah fenomena atau kejadian. Sedangka fungsi laten adalah fungsi yang tidak dikehendaki atau tidak di sadari dari sebuah fenomena (Damsar,2015). 
Fungsi manifes dalam penelitian ini berdasarkan berbagai kebijakan yang telah di programkan oleh pemerintah di masa pandemi COVID-19, mulai dari sosialisasi tentang protokol kesehatan, pembatasan sosial dan kebijakan sistem pembelajaran jaringan (daring). Dari berbagai kebijakan tersebut masyarakat sangat patuh dan turut melaksanakan program dari pemerintah, hal ini dibuktikan dengan $64 \%$ dari responden sangat mentaati peraturan, mulai dari aturan pembatasan sosial, menghindari kerumunan dan membatasi mobilitas dilakukan guna turut membantu dalam pencegahan penyebaran COVID-19.

Selain itu berdasarkan wawancara dengan responden, kebiasaan sehari-hari responden mengalami perubahan di mana setiap keluar rumah menggunakan masker dan lebih sering berada di rumah sejak kasus pasien positif semakin meningkat di masa pandemi COVID-19. Selain itu, sejak terjadinya pandemi COVID-10 remaja menjadi lebih sadar akan pola hidup sehat serta rajin menjaga kesehatan dengan menjalankan pola hidup bersih dan sehat sebagai langkah dalam melindungi diri dari berbagai virus berbahaya.

Fungsi laten dalam penelitian ini yakni terjadinya pernikahan usia remaja khususnya di dua Desa yang ada di Kecamatan Pringgabaya Kabupaten Lombok Timur. Berdasarkan penuturan pihak Kepala Dusun di Desa Bagik Papan dari tahun 2020 hingga tahun 2021 terdapat peningkatan yang cukup signifikan, data menyebutkan bahwa terdapat 143 kasus pernikahan usia remaja. Sedangkan untuk Desa Apitaik terdapat 157 kasus pernikahan usia remaja yang terjadi selama periode tahun 2020 hingga bulan Maret tahun 2021. Habitus yang berasal dari dalam diri sendiri terbentuk karena adanya sebuah pembiasaan. Kebiasaan untuk membuat gerabah sudah ditekuni sejak para pengrajin masih kecil, karena membuat gerabah adalah kegiatan yang turun-temurun hingga sebagian pengrajin menyebutnya sebagai "pusaka" atau warisan dari nenek moyang terdahulu. Kebiasaan ini menjadi sebuah keharusan yang dilakukan untuk bertahan hidup, menjadi kegiatan utama atau menjadi mata pencaharian utama para pengrajin gerabah..

Berdasarkan data tersebut terlihat bahwa terjadi hubungan yang signifikan antara pandemi terhadap pernikahan usia remaja. Kebijakan-kebijakan yang diprogramkan pemerintah di masa pandemi justru menghadirkan adanya fungsi 
yang tidak diharapkan yakni menjadi faktor pemicu terjadinya pernikahan usia remaja. Hal ini terbukti dari hasil analisis data yang dilakukan berdasarkan jawaban responden. Dalam dunia pendidikan pemerintah menerapkan kebijakan adanya sistem pembelajaran jaringan (daring) di masa pandemi COVID-19 guna mencegah adanya kerumunan dan penyebaran virus COVID-19. Nyatanya banyak dari responden yang merasa pembelajaran tidak efektif, $80 \%$ responden menjawab bahwa pembelajaran daring sangat tidak efektif dilakukan dikarenakan 80,3\% responden menjawab tidak dapat memahami materi pembelajaran yang disampaikan oleh guru secara online melalui aplikasi zoom meeting ataupun whatsApp group.

Responden nyatanya tidak memiliki pengetahuan yang cukup terkait pernikahan, masalah reproduksi serta bahaya menikah di usia remaja. Hal ini terlihat dari hasil analisis jawaban responden di mana, 54,7\% dari responden tidak mengetahui bahwa pernikahan di usia remaja dilarang oleh pemerintah. $60 \%$ dari responden juga tidak mengetahui dampak yang akan terjadi jika menikah di usia remaja atau menikah di usia yang terkategori belum cukup. Selain itu, $82,7 \%$ dari responden tidak pernah mempelajari sama sekali terkait dengan masalah reproduksi atau pendidikan tentang seks. Hal ini di karenakan tidak adanya pembahasan terkait

pendidikan seks yang dibahas baik dalam lingkungan sekolah ataupun sosialisasi yang dilakukan di lembaga-lembaga formal. Pemerintah Desa setempat masih belum memiliki program terkait dengan sosialisasi atau seminar tentang kesehatan resproduksi atau bahaya pernikahan di usia remaja serta dampak-dampak yang terjadi akibat pernikahan di usia remaja.

\section{Kesimpulan}

Berdasarkan hasil penelitian yang telah diuraikan pada Bab IV maka dapat ditarik kesimpulan sebagai berikut :

- Terdapat hubungan yang sangat tinggi antara kebijakan pandemi covid-19 terhadap faktor pernikahan usia remaja. Hal ini dibuktikan dengan analisis yang dilakukan menggunakan Uji Korelasi Spearman dengan hasil presentase sebesar 
$81,1 \%$ artinya kebijakan pandemi covid-19 memiliki hubungan yang sangat kuat terhadap faktor pernikahan usia remaja.

Kebijakan pandemi covid-19 memiliki hubungan yang signifikan terhadap faktor pernikahan usia remaja. Sejak terjadinya pandemi covid-19 pemerintah memberlakukan berbagai kebijakan guna mencegah terjadinya penyebaran virus covid-19. Dari berbagai kebijakan tersebut nyatanya berhubungan erat terhadap faktor pernikahan usia remaja. Di mana akibat dari penerapan kebijakan tersebut menimbulkan dampak lain, yakni meningkatnya jumlah pernikahan usia remaja yang disebabkan karena berbagai faktor diantaranya $86,7 \%$ responden mengaku menikah di usia remaja disebabkan karena kondisi sosial ekonomi yang berubah di masa pandemi covid-19. Selain itu, 77,3\% dari responden menikah karena terpengaruh oleh budaya atau tradisi setempat. Faktor lingkungan juga turut menjadi faktor terjadinya pernikahan usia remaja di mana, 70,7\% dari responden menikah karena faktor lingkungan dan teman bermain atau pergaulan.

- Hubungan kebijakan pandemi covid-19 memunculkan adanya fungsi manifes atau fungsi yang diharapkan yaitu masyarakat atau remaja khususnya menjadi lebih taat akan protokol kesehatan, membantu menjaga diri dan orang lain dengan turut membatasi diri keluar rumah dan tidak mengunjungi tempat-tempat keramaian.

Namun, di sisi lain kebijakan yang diterapkan di masa pandemi covid-19 juga memunculkan adanya fungsi laten atau fungsi yang tidak diharapkan atau fungsi yang tidak disadari oleh masyarakat yakni menjadi faktor terjadinya pernikahan usia remaja, dimana dari berbagai kebijakan yang diterapkan pemerintah di masa pandemi covid-19 seperti pembatasan sosial, pembelajaran daring nyatanya semakin membatasi gerak remaja dalam beraktivitas sehingga menjadi faktor pendukung para remaja untuk melakukan pernikahan di usia remaja. Berdasarkan hasil penelitian, pernikahan usia remaja disebabkan karena berbagai faktor diantaranya faktor kondisi sosial ekonomi di mana kebijakan yang diterapkan pemerintah di masa pandemi COVID-19 menghadirkan dampak sosial ekonomi yakni pandemi membuat kondisi ekonomi menurun srta membuat aktivitas sehari-hari responden mulai berubah sehingga cukup 
berdampak serta menjadi salah satu faktor yang mendukung responden melakukan pernikahan usia remaja. Budaya yang berkembang di masyarakat juga turut menjadi faktor terjadinya pernikahan usia remaja. Budaya menikah di usia remaja masih di percaya oleh sebagian masyarakat khususnya masyarakat di Kecamatan Pringgabaya di mana menikah di usia remaja di percaya dapat mencegah anak perempuan dari pergaulan bebas serta mengindari ucapan atau perkataan buruk yang menimpa kelurga. Selain itu masyarakat percaya bahwa anak perempuan yang menikah di usia dewasa atau lebih dari 20 tahun dianggap aib keluarga atau dapat menimbulkan perkataan buruk dari masyarakat. Dampak yang ditimbulkan atau fungsi yang tidak terlihat dan tidak disadari oleh masyarakat dari adanya kepercaya tersebut membuat para remaja atau responden menjadikan hal tersebut alasan untuk melakukan pernikahan di usia remaja. Berdasarkan hasil penelitian, lingkungan menjadi salah satu faktor terjadinya kasus pernikahan usia remaja. Salah satunya lingkungan keluarga, terdapat $60 \%$ dari responden mengaku menikah dikarenakan desakan dari keluarga yang disebabkan karena kondisi dalam keluarga yang mendudung responden untuk melakukan pernikahan di usia remaja. Selain itu lingkungan pertemanan atau lingkungan bermain juga menjadi faktor terjadinya pernikahan usia remaja, terdapat $70,7 \%$ dari responden menikah karena pengaruh lingkungan dan teman bermain yang tidak sehat atau pengaruh perrgaulan bebas sehingga menyebabkan responden melakukan pernikahan usia remaja. 